\title{
Dr Hunter Holmes McGuire, Chief Medical Officer to General Stonewall Jackson
}

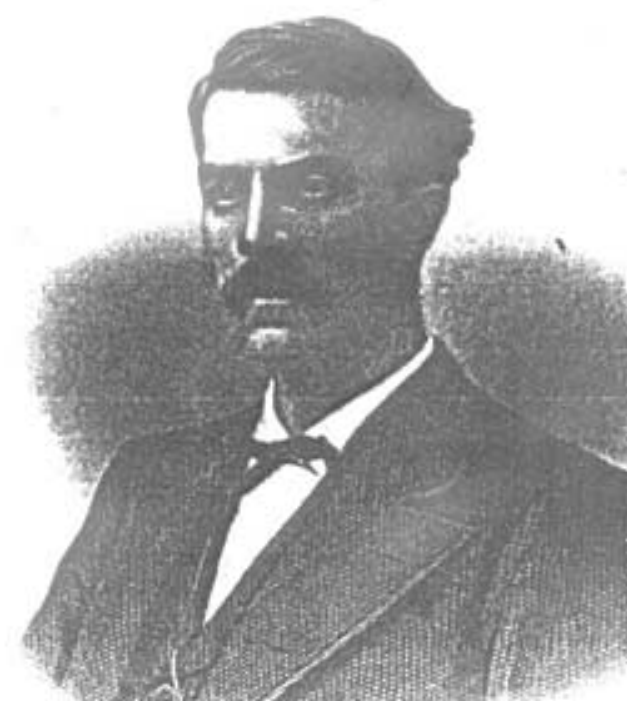

Dr Hunter Holmes Mcguire

The American Civil War was, after the War of Independence, probably the most significant event in the early development of the United States. Its ferocity, and its high casualty and death rates from disease, have all been written about in the home country, but remain largely unknown here in Britain.

In the Civil War, or the "War of the Rebellion' as it was known at the time, the Northern States formed the Union Army of the Potomac and the Southern States, the rebels, formed the Army of the Confederacy.

The first major battle was at Bull Run in Manassa in July 1861. The North expected the battle to be 'a glorious victory' which would decide the war. Spectators had even travelled from Washington south for 27 miles for a day out to watch the battle. The union Army lost heavily. Six hundred and eighty one men were killed, 1011 wounded and 1460 were reported missing. There were no medical services available and no system of casualty evacuation. Wounded lay for days with no relief. Those who could made their own way back to the capital looking for treatment and shelter. The public were outraged.

It quickly became clear that Prisoners of War were being treated badly. Of 214,000 Confederate prisoners held by the Union side, 26,000 (about 12\%) died in captivity. As the numbers increased, a system of exchange of prisoners was begun. In the summer of 1862 an agreement was reached, although discussions were hampered by Lincoln's refusal to acknowledge a state of

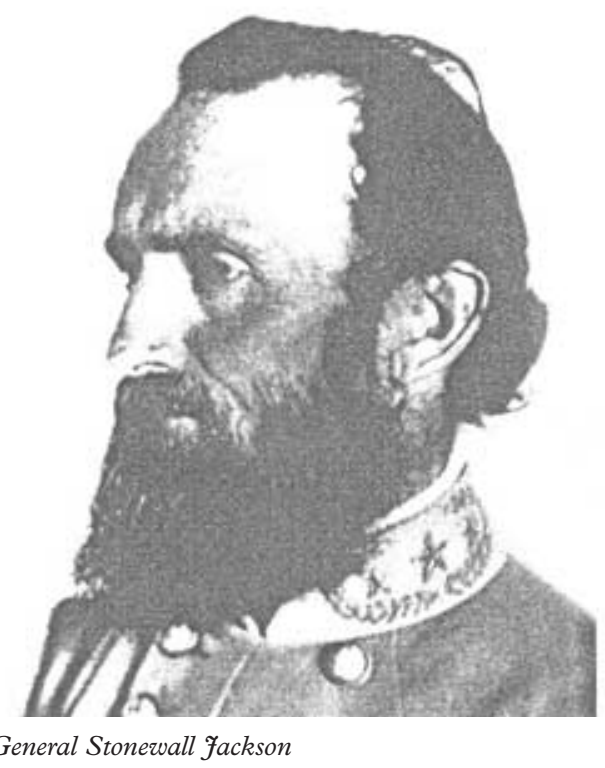

war or recognise the legitimacy of the Confederate Government. The agreement collapsed. Medical Officers were treated like combatants, imprisoned, and prevented from carrying out their medical work. When working, they treated only their own side and not those in the other army. In Europe, captured military surgeons had been allowed to return to their own armies from as long before as the 16th century.

Something had to be done. The credit for bringing to the US war scene full agreement that medical officers were non-combatant belongs to Hunter Holmes McGuire, the CMO to Confederate General Stonewall Jackson. Hunter McGuire was born in the town of Winchester, thirty miles from Harper's Ferry, on 11 th October 1835. He graduated from the College there in 1855. His father was said to be 'the era's most prominent physician and surgeon west of the Blue Mountains'. Hunter soon showed he was not only able but smart. He moved to Philadelphia and along with Francis Lucket, who also later became a Southern Activist, set up a tutorial service for medical students, conducting tutorials and holding quizzes - a true novelty at that time. On the outbreak of war, he hurried from New Orleans where he was working to volunteer for the South, first as a combatant soldier but then as a commissioned medical officer. His ability soon brought him to the fore, and in May 1861, Surgeon General Moore ordered McGuire to report to Stonewall Jackson with the recommendation for
Road,

Perth, PH2 OLX 
promotion to Medical Director of the Army of the Shenandoah.

At their first meeting, it was said that Jackson was unimpressed by the 26 years old, pale, six foot four young man. But the two soon became friends because of McGuire's intense loyalty, skill as a medical officer and administrative ability. McGuire was his medical commander when General Jackson was struck down by his own men at Chancellorsville, amputated his wounded arm, and was with him as he died. Later, McGuire was Chief Surgeon to both Generals Richard Ewell and Jubal Early.

While Hunter Holmes McGuire is remembered as Stonewall Jackson's PMO and personal doctor, his earlier attempts to lessen the current harsh policy towards colleagues are less well recorded. In 1862, after he discovered eight 'enemy' medical officers held prisoner, he asked his General for permission to repatriate them. He had them freed unconditionally, and with a pledge. 'We, surgeons and assistant surgeons, US Army, now prisoners of war in this place, do give our parole of honour, on being unconditionally released, to report in person, singly or collectively, to the Secretary of War in Washington City, that we will use our best efforts that the same number of medical officers of the Confederate States Army, now prisoners, or that may hereafter be taken, to be released on the same terms..' the agreement that MOs be treated differently from combatants soon led to the concept that military doctors would treat enemy with the same care as their own side. It seems almost incomprehensible to us today that such a basic principle had to be put into place, but the fact that it was not standard practice was indeed so. Apart from a short suspension following the refusal of the South to release one officer who had stolen a horse and was suspected of murder - and rightly so - the practice was maintained. And two years later, in 1864, the first Geneva Convention was signed.

Following the War, McGuire was elected Professor of surgery in the Medical College of Virginia in 1865, but like most others in the defeated South, poverty dominated his life; he is said to have had no salary from his College during the twelve years he worked for it, and his private fees were small. Yet he reached high office in several medical organisations, including the American Surgical Association in 1887 and the American Medical Association in 1893. He died following a stroke in 1900. A statue was erected in his memory in Capitol Square near the statue of his much respected commander, General Stonewall Jackson. Part of the caption reads:

'An eminent civilian and military surgeon And beloved physician

An able teacher and vigorous writer; $A$ useful citizen and broad Humanitarian;

Gifted in mind and generous in heart'.

\section{Reference}

The Winchester Accord; James Otis Breeden, Military Medicine, 158, November 1993, pp 689692. 